\title{
Effect of foliar application of potassium silicate on the progress of coffee leaf rust
}

\author{
Ueder Pedro Lopes ${ }^{1}$, Laércio Zambolim ${ }^{1}$, Pedro Nery Souza Neto ${ }^{1}$, Antônio Fernando Souza ${ }^{2}$, Alexandre \\ Sandri Capucho ${ }^{1}$ \& Fabricio de Ávila Rodrigues ${ }^{1}$
}

\begin{abstract}
${ }^{1}$ Departamento de Fitopatologia, Universidade Federal de Viçosa, 36570-000, Viçosa, MG, Brasil; ${ }^{2}$ Instituto Federal de Educação, Ciência e Tecnologia do Espírito Santo, Campus Santa Teresa, Rodovia ES 080 Km 93, 29660-000, Santa Teresa, ES, Brasil
\end{abstract}

Author for correspondence: Laércio Zambolim, e-mail: zambolim@ufv.br

\begin{abstract}
In order to evaluate the effect of potassium silicate spray on the control of coffee leaf rust and coffee yield, an experiment was conducted during the 2005/2006 and 2006/2007 growing seasons on Coffea arabica cv. Catuaí Vermelho IAC 144, in a location situated at an elevation of $850 \mathrm{~m}$ in Coimbra, Minas Gerais, Brazil. The treatments consisted of: 1 - potassium silicate; 2 - potassium silicate + copper hydroxide; 3 - copper hydroxide; 4 - epoxiconazole formulated with pyraclostrobin and 5 - control treatment. Six applications of potassium silicate and copper hydroxide were made twice per month from December to March of each year. Two applications of the systemic fungicide were done in December and March of each year. Potassium silicate alone or in combination with copper hydroxide was not efficient in reducing coffee leaf rust incidence and increasing yield under high incidence of coffee leaf rust.
\end{abstract}

Key words: Coffea arabica, Hemileia vastatrix, copper, silicon.

Rust, caused by the fungus Hemileia vastatrix Berkeley et Broome, is a major coffee disease, occurring in all regions where coffee is grown and reducing production by 35 to $50 \%$ (Zambolim et al., 1999; Waller et al., 2007). The damage caused by this disease is due to premature fall and consequently death of the branches, thus reducing coffee yield in the following year (Zambolim et al., 1992, 1999).

Rust control in Brazil is routinely performed with the use of systemic fungicides sprayed on the leaves (two applications) or applied to soil (one application), and/or copper fungicide (4 to 5 foliar applications) (Zambolim et al., 2002; Souza et al., 2011). Due to increasing concern regarding the environment and health of the consumers, the search for high quality coffee without pesticide residues has been a constant demand (Rodrigues, 2007).

Mineral nutrition is an option that can be used as a complement in disease management (Marschner, 1995). Among the beneficial elements to plants, silicon ( $\mathrm{Si}$ ) has provided promising results in the control of some plant diseases (Datnoff et al., 2007). Some plants when growing in soil with Si differ from those grown without it due to the mechanical resistance of the cells, leaf surface characteristics, and tolerance to abiotic stress (Epstein, 1999). The use of various Si sources has been reported as an alternative for management of various crop diseases of economic importance (Menzies et al., 1991, Bowen et al., 1992; Chérif et al., 1994; Fauteux et al., 2005; Datnoff et al., 2007; Carré-Missio, 2012). Rice plants grown in soil with increasing Si rates presented reduced severity of sheath blight caused by Rhizoctonia solani Kühn (Rodrigues et al., 2002). Cucumber plants inoculated with Podosphaeria fuliginea (powdery mildew) and grown in nutrient solution supplemented with sodium silicate showed fewer lesions per leaf, low disease severity and reduced germination of conidia compared with plants non-supplied with $\mathrm{Si}$ (Menzies et al., 1991; Liang et al., 2005). It is known that Si can also increase the resistance of cucumber to Pythium ultimum, where the infected root cells from plants supplied with this element responded more quickly to the pathogen's attack due to the accumulation of phenolic compounds (Chérif et al., 1994). Spraying grape leaves with potassium silicate reduced the number of lesions caused by Uncinula necator (powdery mildew) by $14 \%$ because the inhibitory effect of Si on conidial germination (Bowen et al., 1992).

Coffee plants cv. Catuaí vermelho IAC 144 supplied with $\mathrm{Si}$ in a nutrient solution and inoculated with Hemileia vastatrix did not present any alterations on several epidemiological components (Carré- Missio et al., 2009). However, Carré-Missio et al. (2012) observed a reduction in the severity of coffee leaf rust after foliar spray of potassium silicate. For the pathosystem coffeeMeloidogyne exigua, Silva et al. (2010) observed a reduction in the number of galls on the roots of plants growing in soil amended with calcium silicate. Santos \& Botelho (2005) observed a reduction in severity of brown eye leaf spot with the application of sodium silicate to the soil. Pereira et al. (2009) reported a reduction in the severity of coffee leaf rust 
with foliar application of potassium silicate, but there was no increase in the activities of chitinase, $\beta$-1,3-glucanases, peroxidases, polyphenol oxidases, phenylalanine ammonialyases and lipoxygenases. Duarte et al. (2009) did not find significant effect of potassium silicate on the reduction of area under the soybean rust progress curve as well as yield. When the fungicide mancozeb was mixed with potassium silicate at $1.2 \mathrm{~kg} / \mathrm{ha}$, the progress of soybean rust was not affected. A similar result was found with potassium silicate alone or mixed with mancozeb + cymoxanil on the control of late blight of potato (Duarte et al., 2008) and with "Calda Viçosa" (a mixture of copper and micronutrients) to control ramularia leaf spot on cotton (Aquino et al., 2008). On the other hand, Rodrigues et al. (2009) reported decreased soybean rust severity by foliar application of potassium silicate at rates ranging from 8 to $60 \mathrm{~g} / \mathrm{L}$.

Most studies involving the application of soluble Si sources provides this element via root, soil or nutrient solution to the plants. There are no studies on the use of $\mathrm{Si}$ in commercial coffee cultivation. Therefore, the effect of foliar-applied Si for the control of coffee leaf rust and maintenance of the productive potential of coffee plants are strategies that should be considered to reduce yield losses caused by this disease. Therefore, this study aimed to evaluate whether the application of potassium silicate could reduce the incidence of coffee leaf rust.

The experiment was conducted during the 2005/2006 and 2006/2007 growing seasons in Coimbra, state of Minas Gerais, Brazil, at an elevation of $850 \mathrm{~m}$, using five yearold plants of Coffea arabica L. cv. Catuaí Vermelho IAC 144 , spaced $2.5 \mathrm{~m} \times 1.0 \mathrm{~m}$. The experiment was setup in a randomized block design with five treatments and four replications. Each experimental unit consisted of ten coffee plants, where the central five were considered the useful portion of each replication and were used for evaluation of rust incidence and productivity.

The treatments consisted of: 1 - potassium silicate (Fertisil, INEOS Silicas Ltda., $7.2 \mathrm{~kg} / \mathrm{ha}$ of the commercial product); 2 - potassium silicate $(7.2 \mathrm{~kg} / \mathrm{ha}$ of the commercial product) + copper hydroxide (Kocide 101, DuPont, $1.5 \mathrm{~kg} /$ ha of the commercial product); 3 - copper hydroxide; 4 systemic fungicide epoxiconazole + pyraclostrobin (Opera, Basf, $1.5 \mathrm{~L} / \mathrm{ha}$ ); and 5 - control plants (no application of products). The composition of the potassium silicate was: $\mathrm{K}_{2} \mathrm{O}=13 \%, \mathrm{SiO}_{2}=26.59 \%$, and $\mathrm{Na}_{2} \mathrm{O}=0.5 \%$ ). Hydrochloric acid $(19.72 \mathrm{~L} / \mathrm{ha})$ and potassium chloride $(8.0 \mathrm{~L} / \mathrm{ha})$ at concentration of $1 \mathrm{~mol} / \mathrm{L}$ were added to the potassium silicate solutions. Products were sprayed with a manual backpack sprayer integrated with an empty cone nozzle, calibrated to apply $400 \mathrm{~L} / \mathrm{ha}$. Potassium silicate and copper hydroxide were sprayed twice per month (every two weeks) from December to March in a total of six applications of each product per year. Plants sprayed with epoxiconazole + pyraclostrobin received two applications, the first in December and the second in February of each year.
Evaluation of coffee leaf rust was performed monthly by destructive leaf sampling. Ten fully developed leaves were collected on the third or fourth pair of the branches around the plants, totaling fifty leaves sampled by each replication. Disease incidence was evaluated by quantifying the percentage of leaves that had at least one rust pustule containing uredospores. Data from disease incidence was used to calculate the area under rust progress curve (AURPC) according to Shaner \& Finney (1977). Plants of each replication were harvested when they presented at least $70 \%$ of red coffee beans and data was transformed to beneficiated coffee bean bags of $60 \mathrm{~kg}$ per hectare.

For determining foliar Si concentration, a total of 50 leaves from all the replications of each treatment were collected one week before harvesting, washed with deionized water, dried in an oven with forced air at $60^{\circ} \mathrm{C}$ for 72 hours, and ground to pass through a 40-mesh screen with a Thomas-Wiley mill (Thomas Scientific). Silicon in leaf tissue was determined by a colorimetric analysis on $0.1 \mathrm{~g}$ of dried and alkali digested tissue (Korndörfer et al., 2004). For statistical analysis, after verification of the assumptions of normality, homogeneity, and independence of experimental error, data from AURPC and productivity were subjected to analysis of variance and means compared by Tukey's test at $5 \%$ of significance.

In the first experiment (2005/2006), rust incidence reached values above $90 \%$ in the control plants (no application of product) (Figure 1A). In the second experiment (2006/2007), rust incidence was low and did not exceed $60 \%$ in the control treatment (Figure 1B). The spray of potassium silicate at $7.2 \mathrm{~kg} / \mathrm{ha}$ was not effective in reducing rust incidence as observed by the elevated values of the AURPC in experiment 1 (Table 1). Application of copper in the form of copper hydroxide $(1.5 \mathrm{~kg} / \mathrm{ha})$ reduced rust incidence by $64 \%$ when compared with plants that did not receive any product application, although with lower efficiency than epoxiconazole + pyraclostrobin. The mixture of potassium silicate with copper hydroxide did not result on coffee leaf rust control and the reduction of rust incidence was probably due solely to the copper fungicide. In the second experiment, rust incidence was lower in all treatments without difference between plants sprayed with copper hydroxide, potassium silicate or epoxiconazole + pyraclostrobin, but these treatments were different from the control plants (Table 1). Potassium silicate has showed promising results for coffee leaf rust control in a preventive way when rust germination is low (35\%) (Carré-Missio et al., 2012). The local protection gained by potassium silicate spray to reduced coffee leaf rust was prolonged by up to 25 days (Carré-Missio et al., 2012). Foliar application of potassium silicate must have reduced the intensity of rust by created a physical barrier on the surface after its polymerization, which negatively affected the sporulation of $H$. vastatrix. Other mechanisms by which $\mathrm{Si}$ confers resistance to certain diseases are due to the physical barrier formed by the deposition of this element under the cuticle 

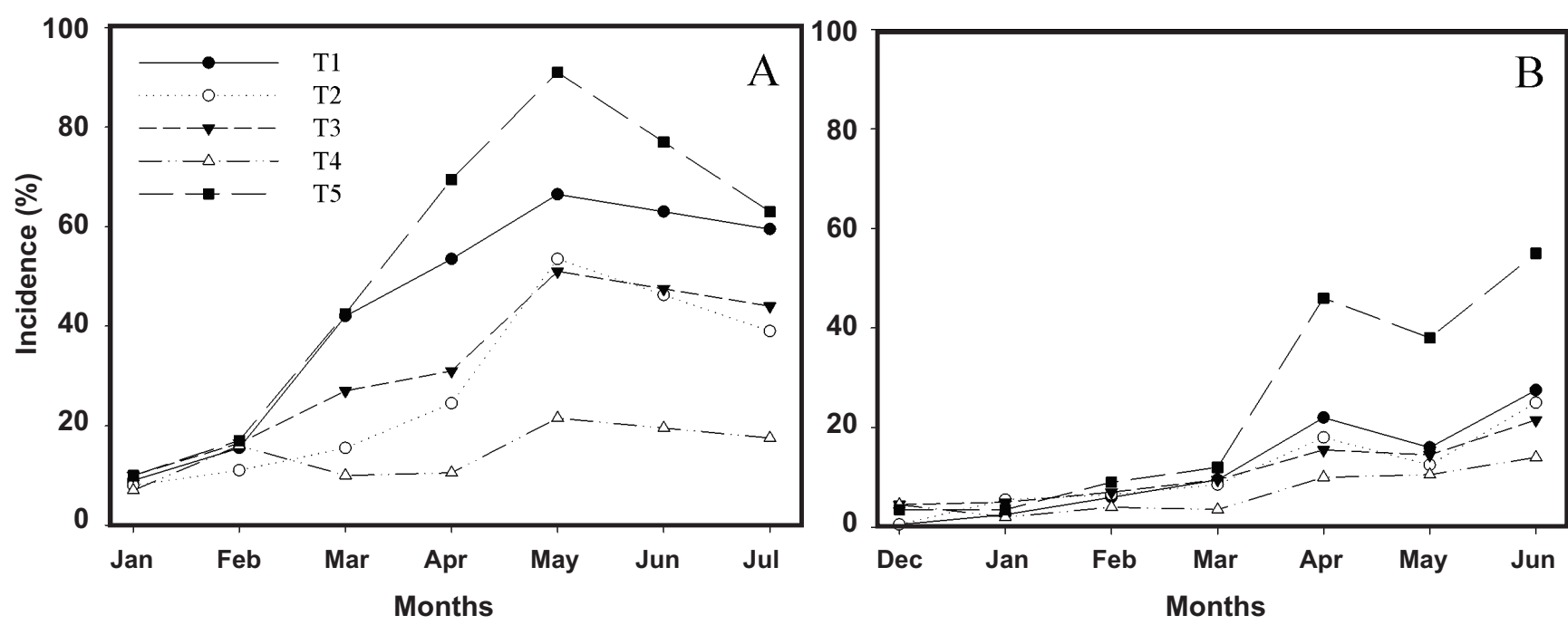

FIGURE 1 - Incidence of coffee leaf rust on plants that received the application of potassium silicate (7.2 kg) (T1), potassium silicate (7.2 $\mathrm{kg})+$ copper hydroxide $(1.5 \mathrm{~kg} / \mathrm{ha})(\mathrm{T} 2)$, copper hydroxide $(1.5 \mathrm{~kg} / \mathrm{ha})(\mathrm{T} 3)$, epoxiconazole + pyraclostrobin $(133+50 \mathrm{~g} / \mathrm{L}$ was $1.5 \mathrm{~L} / \mathrm{ha})$ (T4) and control treatment (T5), in experiments 1 (A) and 2 (B).

TABLE 1 - Area under rust progress curve (AURPC) and yield (bags of beans coffee per hectare) in coffee plants submitted to the application of potassium silicate alone or in combination with copper hydroxide

\begin{tabular}{|c|c|c|c|}
\hline \multirow[t]{2}{*}{ Treatments } & \multicolumn{2}{|c|}{ AURPC } & \multirow[t]{2}{*}{ Yield $^{1}$} \\
\hline & Exp. 1 & Exp. 2 & \\
\hline Potassium silicate & $8942.5 \mathrm{a}$ & $2343.3 \mathrm{~b}$ & $26.0 \mathrm{a}$ \\
\hline Potassium silicate + Copper hydroxide & $5753.0 \mathrm{~b}$ & $2112.8 \mathrm{~b}$ & $36.2 \mathrm{ab}$ \\
\hline Copper hydroxide & $6550.0 \mathrm{~b}$ & $2096.3 \mathrm{~b}$ & $33.6 \mathrm{ab}$ \\
\hline Epoxiconazole + pyraclostrobin & $2728.0 \mathrm{c}$ & $1264.5 \mathrm{~b}$ & $47.5 \mathrm{~b}$ \\
\hline Control & $10751.3 \mathrm{a}$ & $4574.0 \mathrm{a}$ & $21.4 \mathrm{a}$ \\
\hline
\end{tabular}

Means followed by the same letter in each column do not differ by Tukey's test at $p \leq 0.05$.

${ }^{1}$ Yield average of coffee in 2005/2006 (Exp. 1) and in 2006/2007 (Exp. 2) growing seasons. Benefitiated bags means 60 beneficiated kg of coffee beans.

and on the wall of the epidermal cells (Kim et al., 2002) or by the enhancement of defense mechanisms (Datnoff et al., 2007). However, Carré-Missio et al. (2009) reported that the activities of glucanases, chitinases, and peroxidases only increased in the presence of Hemileia vastatrix, regardless of $\mathrm{Si}$ in the nutrient solution. Datnoff et al. (2007) also reported that $\mathrm{Si}$ has no capacity to translocate from older to newer leaves or even from one application site to another. Thus, to ensure reduced diseases intensities, possibly by their osmotic effect, potassium silicate should be constantly applied to all leaves of the plant (Rodrigues et al., 2009, 2010) and this is very difficult to achieve in three to fouryears old coffee trees.

In the present study, there was no increase in leaf Si concentration for plants sprayed with potassium silicate, indicating that the product was not absorbed by the leaves of the coffee trees (data not shown). These results corroborate with the report of Carré-Missio et al. (2012) showing that the foliar application of potassium silicate at a rate of 20 $\mathrm{g} / \mathrm{L}$ did not increase Si concentration on coffee leaves. However, if there was polymerization of silicate in the leaf surface, it will not be enough to slow disease progress under field conditions. This may be related to the fact that under these conditions, the occurrence of rain can remove the polymerized Si on the leaf surfaces.

The coffee plants that received the application of potassium silicate showed similar productivities to plants that did not receive the application of any product due to the fact that potassium silicate was not effective in the control of coffee leaf rust in the first year when the disease incidence reached high values. On plants sprayed with potassium silicate + copper hydroxide, yield increased by $28 \%$ compared to plants sprayed only with potassium silicate. In plants sprayed with copper hydroxide, there was $62 \%$ increase in yield compared to plants that did not receive the application of any product. Plants that received the application of epoxiconazole + pyraclostrobin showed an increase of $122 \%$ in yield compared to plants that did 
not receive the product application. The gain in yield is related to the reduction of rust incidence provided by the systemic fungicide and the consequent reduction in defoliation caused by the disease. It is known that coffee leaf rust causes intense defoliation in coffee plants leading to a reduced yield (Zambolim et al., 1999; Waller et al., 2007). Thus, an efficient control of coffee leaf rust using copper hydroxide or epoxiconazole + pyraclostrobin can result in the maintenance of yield potential of the coffee trees. Potassium silicate did not present an efficient control of coffee rust which resulted in lower yield. Both copper hydroxide and potassium silicate were applied alone and in combination every 15 days, in a total of six applications. Since the copper hydroxide was effective in reducing rust incidence in comparison to potassium silicate, it is suggested that in the years of higher rust incidence it is necessary to perform many applications of copper fungicide. There was no significant difference between the control treatments and potassium silicate both alone and together with copper hydroxide for foliar $\mathrm{Si}$ concentration indicating that the available $\mathrm{Si}$ in the potassium silicate was not efficiently absorbed by the leaves.

The results of this study showed that the foliar application of silicate alone was not efficient for the control of coffee leaf rust under high disease incidence. Also, there was no synergistic effect when the potassium silicate was combined with copper hydroxide. Therefore, the application of potassium silicate to coffee plants is not an effective strategy that can be used to control coffee rust and, therefore, increase yield under high disease pressure on field conditions.

\section{REFERENCES}

Aquino LA, Berger PG, Rodrigues FA, Zambolim L, Ogoshi F, Miranda LM, Lélis MM (2008) Controle alternativo da mancha de ramularia do algodoeiro. Summa Phytopatologica 34:131136.

Bowen P, Menzies J, Ehret D (1992) Soluble silicon sprays inhibit powdery mildew development on grape leaves. Journal of the American Society for Horticultural Science 117:906-12.

Carré-Missio V, Rodrigues FA, Schurt DA, Pereira SC, Oliveira MGA, Zambolim L (2009) Ineficiência do silício no controle da ferrugem do cafeeiro em solução nutritiva. Tropical Plant Pathology 34:416-421.

Carré-Missio V, Rodrigues FA, Schurt DA, Moreira WR, Rezende DC, Korndorfer GH, Zambolim L (2012) Proteção local, não sistêmica, do silicato de potássio reduz os sintomas da ferrugem do cafeeiro. Tropical Plant Pathology 37:275-280.

Chérif M, Asselin A, Bélanger RR (1994) Defense responses induced by soluble silicon in cucumber roots infected by Pythium spp. Phytopathology 84:236-242.

Datnoff LE, Rodrigues FA, Seebold KW (2007) Silicon and plant disease. In: Datnoff LE, Elmer WH, Huber DM (Eds). Mineral Nutrition and Plant Disease. St. Paul MN, EUA. APS Press. pp. 233-246.
Duarte HSS, Zambolim L, Rodrigues FA, Rios JA (2008) Efeito do silicato de potássio isoladamente e em mistura com fungicida no controle da requeima da batateira. Summa Phytopathologica 34:68-70.

Duarte HSS, Zambolim L, Rodrigues FA, Rios JA, Lopes UP (2009) Silicato de potássio, acibenzolar-S-metil e fungicidas no controle da ferrugem da soja. Ciência Rural 39:2272-2277.

Epstein E (1999) Silicon. Annual Review of Plant Physiology and Plant Molecular Biology 50:641-664.

Fauteux F, Rémus-Borel W, Menzies JG, Bélanger RR (2005) Silicon and plant disease resistance against pathogenic fungi. FEMS Microbiology Letters 249:1-6.

Kim SG, Kim KW, Park EW, Choi D (2002) Silicon-induced cell wall fortification of rice leaves: A possible cellular mechanism of enhanced host resistance to blast. Phytopathology 92:1095-1103.

Korndörfer GH, Pereira HS, Nolla A (2004) Análise de Silício: Solo, Planta e Fertilizante (Boletim Técnico). Uberlândia MG. GPSi/ICIAG/UFU.

Liang YC, Sun WC, Si J, Römheld V (2005) Effects of foliar and root applied silicon on the enhancement of induced resistance to powdery mildew in Cucumis sativus. Plant Pathology 54:678685.

Marschner H (1995) Mineral Nutrition of Higher Plants. London UK. Academic Press.

Menzies JG, Ehret DM, Glass ADM, Helmer T, Koch S, Seywerd F (1991) The effects of soluble silicon on the parasitic fitness of Sphaerotheca fuliginea (Schlect. Fr.) Poll. on Cucumis sativus L. Phytopathology 81:84-88.

Pereira SC, Rodrigues FA, Carré-Missio V, Oliveira MGA, Zambolim L (2009) Efeito da aplicação foliar de silício na resistência à ferrugem e na potencialização da atividade de enzimas de defesa em cafeeiro. Tropical Plant Pathology 34:223-230.

Rodrigues R (2007) Alimento seguro e rastreabilidade: Uma parceria salutar. In: Zambolim L (Ed.). Rastreabilidade para a Cadeia Produtiva do Café. Visconde do Rio Branco MG, Brazil. Suprema Gráfica e Editora. pp.1-5.

Rodrigues FA, Duarte HSS, Domiciano GP, Souza CA, Korndörfer, GH, Zambolim L (2009) Foliar application of potassium silicate reduces the intensity of soybean rust. Australasian Plant Pathology 38:366-372.

Rodrigues FA, Duarte HSS, Rezende DC, Wordell Filho JA, Korndörfer GH, Zambolim L (2010) Foliar spray of potassium silicate on the control of angular leaf spot on beans. Journal of Plant Nutrition 33:2082-2093.

Rodrigues FA, Vale FXR, Korndörfer GH, Prabhu A, Datnoff LE, Oliveira AMA, Zambolim L (2002) Influence of silicon on sheath blight of rice in Brasil. Crop Protection 22:23-29.

Santos Botelho DM, Pozza EA, Pozza AAA, Carvalho JG, Botelho CE, Souza PE (2005) Intensidade da cercosporiose em mudas de cafeeiro em função de fontes e doses de silício. Fitopatologia Brasileira 30:582-588.

Shaner G, Finney RE (1977) The effect of nitrogen fertilization on the expression of slow-mildewing resistance in Knox wheat. Phytopathology 67:1051-1056.

Silva RV, Oliveira RDL, Nascimento KJT, Rodrigues FA (2010) Biochemical responses of coffee resistance against Meloidogyne 
exigua mediated by silicon. Plant Pathology 59:586-593.

Souza AF, Zambolim L, Jesus Júnior WC, Cecon PR (2011) Chemical approaches to manage coffee leaf rust in drip irrigated trees. Australasian Plant Pathology 40:293-300.

Waller JM, Bigger M, Hillocks RJ (2007) Coffee pests, diseases and their management. Oxfordshire UK. CAB International.

Zambolim L, Acuña RS, Vale FXR, Chaves GM (1992) Influência da produção do cafeeiro sobre o desenvolvimento da ferrugem
(Hemileia vastatrix). Fitopatologia Brasileira 17:32-35.

Zambolim L, Vale FXR (1999) Manejo integrado das doenças do cafeeiro. In: Zambolim L. (Ed.) I Encontro Sobre Produção de Café com Qualidade. Visconde do Rio Branco MG, Brazil. Suprema Gráfica e Editora. pp.134-215.

Zambolim L, Vale FXR, Costa H, Pereira AA, Chaves GM (2002) Epidemiologia e controle integrado da ferrugem do cafeeiro. In: Zambolim L (Ed.) O Estado da Arte de Tecnologias de Produção de Café. Viçosa MG, Brazil. Editora UFV. pp. 369-450.

TPP 2013-0006 - Received 18 January 2013 - Accepted 14 July 2013

Section Editor: Marciel J. Stadnik 